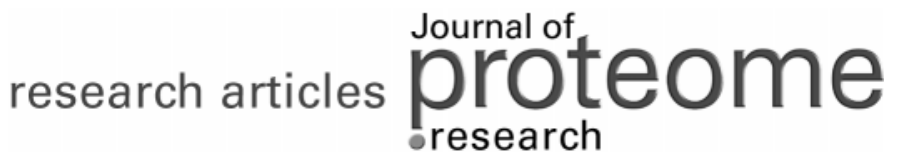

\section{The Platelet Microparticle Proteome}

\author{
Benjamin A. Garcia, ${ }^{\dagger, \perp}$ David M. Smalley, ${ }^{\ddagger, \S, \perp}$ HyungJun Cho, Jeffrey Shabanowitz, ${ }^{\dagger}$ \\ Klaus Ley, ${ }^{\ddagger, \S}$ and Donald F. Hunt*,
}

\begin{abstract}
Department of Chemistry, University of Virginia, Charlottesville, Virginia 22904, Department of Biomedical Engineering, Molecular Physiology and Biological Physics, and Cardiovascular Research Center, University of Virginia, Charlottesville, Virginia 22908, Mellon Biomarker Discovery Center, Cardiovascular Research Center, University of Virginia, Charlottesville, Virginia 22908, Division of Biostatistics and Epidemiology, Department of Health Evaluation Sciences, University of Virginia, Charlottesville, Virginia 22908, and Departments of Chemistry and Pathology, University of Virginia, Charlottesville, Virginia 22904
\end{abstract}

Received March 25, 2005

\begin{abstract}
Platelet-derived microparticles are the most abundant type of microparticle in human blood and contribute to many biologically significant processes. Here, we report the first proteomic analysis of microparticles generated from activated platelets. Using 1D SDS-PAGE and liquid chromatography coupled to a linear ion trap mass spectrometer, the identification of 578 proteins was accomplished using a minimum of $5 \mathrm{MS} / \mathrm{MS}$ detections of at least two different peptides for each protein. These microparticles displayed many proteins intrinsic to and well-characterized on platelets. For example, microparticles in these experiments were found to contain membrane surface proteins including GPIIla, GPIlb, and P-selectin, as well other platelet proteins such as the chemokines CXCL4, CXCL7, and CCL5. In addition, approximately 380 of the proteins identified were not found in two previous studies of the platelet proteome. Since several of the proteins detected here have been previously implicated in microparticle formation and/or pathological function, it is hoped that this study will help fuel future work concerning the possible role of microparticles in various disease states.
\end{abstract}

Keywords: microparticle • platelet • proteome • mass spectrometry

\section{Introduction}

Microparticles (MPs) are small $(\sim 0.1 \mu \mathrm{m})$ membrane vesicles released from a variety of cells upon activation. Their plasma levels are elevated in many pathological conditions, including lupus, acute coronary syndrome, diabetes, sepsis, and multiple sclerosis. ${ }^{1-5}$ MPs were discovered as a component of the blood which promoted coagulation due to the presence of anionic phospholipids on their outer surface, ${ }^{6}$ and have traditionally been viewed as markers of cellular activation and/or damage generated by the random blebbing of cell membranes. However, MPs contain a unique subset of proteins derived from the parent cell, ${ }^{7-9}$ and in recent years it has become clear that MPs have important biological functions. The best characterized of these functions is their participation in blood coagulation by providing a source of tissue factor. ${ }^{10}$ Numerous studies have shown that MPs, isolated either from plasma or from

* To whom correspondence should be addressed. Tel: (434) 924-3610. Fax: (434) 982-2781. E-mail: dfh@virginia.edu.

${ }^{\dagger}$ Department of Chemistry.

‡ Department of Biomedical Engineering, Molecular Physiology and Biological Physics, and Cardiovascular Research Center.

${ }^{\S}$ Mellon Biomarker Discovery Center, Cardiovascular Research Center.

"Division of Biostatistics and Epidemiology, Department of Health Evaluation Sciences.

$\nabla$ Departments of Chemistry and Pathology.

${ }^{\perp}$ These authors contributed equally to this work. supernatants of stimulated cells, increase expression of adhesion molecules on endothelial cells and monocytes, ${ }^{11}$ stimulate the release of cytokines, ${ }^{12,13}$ alter vascular reactivity, ${ }^{14}$ induce angiogenesis, ${ }^{15}$ and may even be involved in cancer metastasis. ${ }^{16}$

Platelet-derived MPs (Pt-MPs), which account for over $90 \%$ of the plasma microparticles from healthy individuals, ${ }^{17}$ have been implicated in many of these effects. ${ }^{14,15,18,19}$ While considerable attention has been given to the effect of these MPs on vascular function, little is known about their protein composition. Analysis of the protein content of microparticles has been limited to a few membrane proteins exposed on microparticles that can be monitored by flow cytometry analysis. ${ }^{17,20}$ Nevertheless, no information exists on the intravesicular protein content of platelet microparticles. The goal of this study is to examine the proteome of Pt-MPs and compare it with recent publications describing the platelet proteome. Currently, we are not aware of any studies which examine the difference between the protein composition of platelets and platelet derived MP.

Here we use mass spectrometry-based proteomics to examine the proteome of isolated microparticles generated from platelets treated with $\mathrm{ADP}$ and then compare this proteome with that of the platelet proteome. Microparticle protein was separated using 1D SDS-PAGE and resulting broad gel sections 


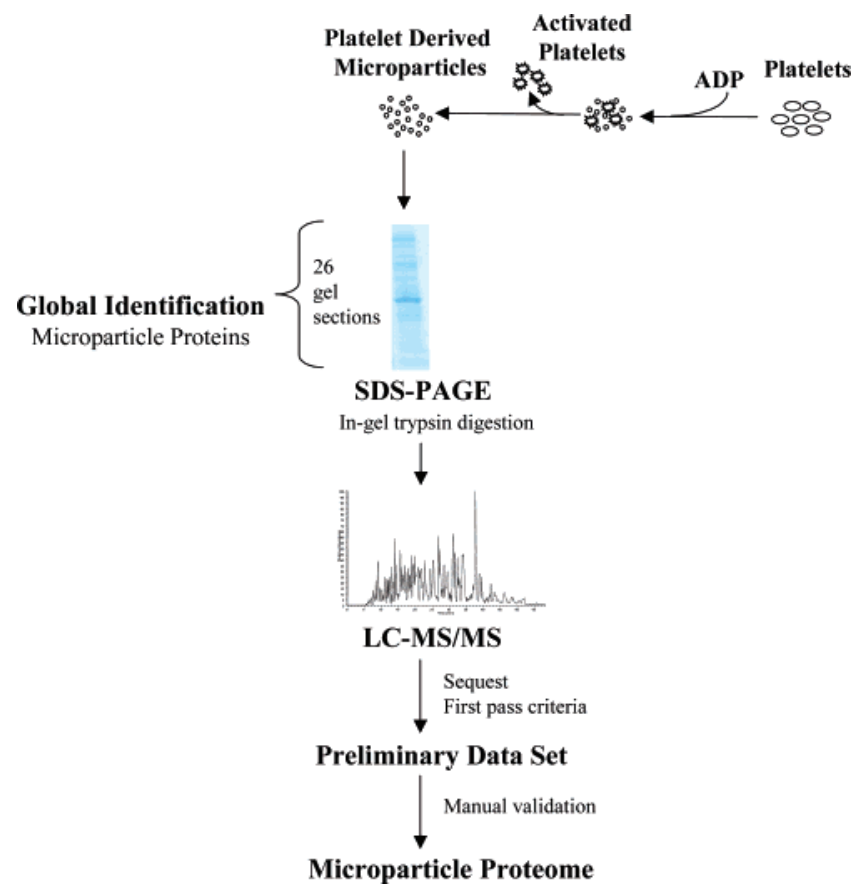

Figure 1. Strategy for analyzing the proteome of platelet-derived microparticles. Microparticles were generated by activating platelets with the agonist, ADP, fractionated by centrifugation, and lysed with SDS. The resulting protein samples were fractionated by SDS-PAGE on a $4-20 \%$ gel that was then sliced into 26 bands of equal size. Proteins in each band were digested with trypsin and the resulting peptides were analyzed by LCMS/MS.

were digested with trypsin and subjected to MS/MS analysis on a linear ion trap mass spectrometer. We identify 578 plateletderived microparticle proteins, 380 of which have not been previously described as constituents of the platelet proteome. Proteins characterized in this research will help establish a working proteome that can be used to probe future questions concerning microparticle function during distinct cellular processes or disease conditions, especially cardiovascular disorders.

\section{Materials and Methods}

Isolation of Platelets and Generation of Microparticles. The strategy for the generation and mass spectrometric identification of proteins in platelet-derived microparticles is shown in Figure 1. Platelets were isolated as described. ${ }^{21}$ Briefly, $55 \mathrm{~mL}$ of human blood was collected by venipuncture into $1 / 10$ volume of acid-citrate-dextrose ( $85 \mathrm{mM}$ trisodium citrate, 83 $\mathrm{mM}$ dextrose, and $21 \mathrm{mM}$ citric acid) solution. Platelet rich plasma (PRP) was obtained by centrifugation of the above sample at $110 \times g$ for $15 \mathrm{~min}$ to remove $\mathrm{RBC}$ and leukocytes. Platelets were pelleted by centrifugation at $710 \times g$ for $15 \mathrm{~min}$. and washed three times, the first two with wash buffer 1 (120 $\mathrm{mM}$ sodium chloride, $13 \mathrm{mM}$ sodium citrate, and $30 \mathrm{mM}$ dextrose, $\mathrm{pH}$ 7.0) and then with wash buffer 2 (154 mM sodium chloride, $10 \mathrm{mM}$ TRIS-HCl, $1 \mathrm{mM}$ EDTA, $\mathrm{pH}$ 7.4). The final pellet was resuspended in $10 \mathrm{~mL}$ of Tyrode's buffer with (1.5 $\mathrm{mM}$ calcium chloride and $0.4 \mathrm{mM}$ magnesium chloride) and centrifuged one additional time at $110 \times g$ to remove any remaining red blood cells or debris. To $5 \mathrm{~mL}$ of the platelet suspension, $5 \mu \mathrm{L}$ of a $10 \mathrm{mM}$ ADP solution was added to generate platelet-derived microparticles. Following a $10 \mathrm{~min}$ incubation period, $50 \mu \mathrm{L}$ of EGTA (200 mM) was added and the sample was centrifuged at $710 \times g$ for $15 \mathrm{~min}$ to separate platelets from platelet-MP. Microparticles were pelleted by centrifugation of the supernatant at $150000 \times g$ for $90 \mathrm{~min}$ at $4^{\circ} \mathrm{C}$ as previously described. ${ }^{22}$

Fluorescence-Activated Cell Sorting (FACS) Analysis of Blood and Purified Platelets/Microparticles. Purified platelets, microparticles or anticoagulated blood were stained with the following fluorescein isothiocyanate (FITC)-anti-CD235a (Glycophorin A) or (PE)-conjugated anti-CD41 (GPIIb) to verify the correct forward and side scatter of RBCs and platelets, respectively. Both antibodies, and their corresponding isotype controls were from BD Biosciences (San Diego, CA). The location of microparticles was determined by Annexin V (FITC- or Allophycocyanin (APC)-conjugated) positive events on particles less than $1 \mu \mathrm{m}$ in buffer containing $10 \mathrm{mM} \mathrm{CaCl}_{2}$. Flow cytometry was performed on a Becton Dickinson FACScan using Cellquest software (Becton Dickinson, Palo Alto, CA). Data were analyzed using FlowJo software (Tree Star, Inc, Ashland, OR).

In-Gel Digestion. Cell and microparticle pellets were resuspended in a minimal volume of PBS (Phosphate buffered saline, $\mathrm{pH}$ 7.4) and a small aliquot was taken for protein analysis using the Micro BCA Protein Assay (Pierce Biotechnology, Inc., Rockford, IL). One hundred micrograms of each sample was resuspended with water to $40 \mu \mathrm{L}$ and $10 \mu \mathrm{L}$ of $5 \times$ SDS-PAGE loading buffer (0.5 M Tris, $\mathrm{pH} 6.8,10 \%$ SDS, $38 \%$ glycerol, $0.1 \%$ bromophenol blue) was added. The samples were immediately heated to $95^{\circ} \mathrm{C}$ for $5 \mathrm{~min}$., allowed to cool to room temperature, and centrifuged for $2 \mathrm{~min}$. at $14000 \mathrm{rpm}$ prior to loading. Microparticle protein (50 $\mu \mathrm{g}$ ) was separated using $4-20 \%$ SDSPAGE precast gels (Biorad, Hercules, CA) at $150 \mathrm{~V}$ and stained with Coomassie blue as previously described. ${ }^{23}$ For an extensive mass spectrometric interrogation of the microparticle proteome, the gel lane containing the sample was cut into 26 equally sized sections irrespective of staining intensity and ingel digestion of the bands performed as previously described. ${ }^{24}$ Briefly, gel sections were sliced into $1.0 \mathrm{~mm}$ cubes and washed with $100 \mu \mathrm{L}$ of a $0.1 \mathrm{M}$ ammonium bicarbonate buffer, $\mathrm{pH}$ 8.0. The diced cubes were next reduced and alkylated using 0.01 $\mathrm{M}$ dithiothreitol and $0.05 \mathrm{M}$ iodoacetamide, respectively. The gel pieces were then dehydrated and re-swollen in a minimal volume of $0.1 \mathrm{M}$ ammonium bicarbonate buffer containing 12.5 $\mathrm{ng} / \mu \mathrm{L}$ trypsin and allowed to react overnight at room temperature. Peptides were extracted with $100 \mu \mathrm{L}$ of a solution of $50 \%$ acetonitrile containing $5.0 \%$ formic acid for $15 \min$ ( 2 cycles), followed by a further extraction with $100 \%$ acetonitrile. The extracted peptide solutions were then concentrated to about a $1.0 \mu \mathrm{L}$ volume. The samples were brought up to $20 \mu \mathrm{L}$ with $0.1 \%$ acetic acid for mass spectrometry analysis.

Mass Spectrometry. Each gel section solution sample was loaded onto a $360 \mu \mathrm{m}$ o.d. $\times 75 \mu \mathrm{m}$ i.d. microcapillary fused silica precolumn packed with C18 irregular 5-20 $\mu \mathrm{m}$ sized resin. After sample loading, the precolumn was washed with $0.1 \%$ acetic acid for 15 min to remove any buffer salts or gel contaminants. The precolumn was then connected to a 360 $\mu \mathrm{m}$ o.d. $\times 50 \mu \mathrm{m}$ i.d. analytical column packed with $\mathrm{C} 18$ regular $5 \mu \mathrm{m}$ sized resin constructed with an integrated electrospray emitter tip. ${ }^{25}$ Samples were gradient eluted from a model 1100 series HPLC solvent delivery system (Agilent, Palo Alto, CA) directly into a Finnigan LTQ ion trap mass spectrometer (Thermo Electron, San Jose, CA) at a flow rate of $60 \mathrm{nl} / \mathrm{min}$. The nano-flow HPLC gradient used was $5-38 \% \mathrm{~B}$ in $70 \mathrm{~min}$, $38-100 \% \mathrm{~B}$ in $15 \mathrm{~min}$ and $100-0 \% \mathrm{~B}$ in $5 \mathrm{~min}$ (Solvent $\mathrm{A}=$ 
A.

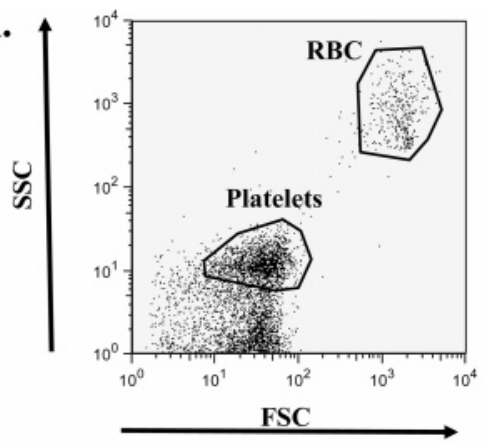

C.

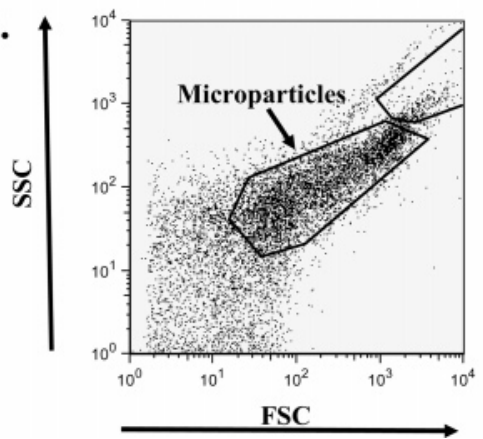

B.

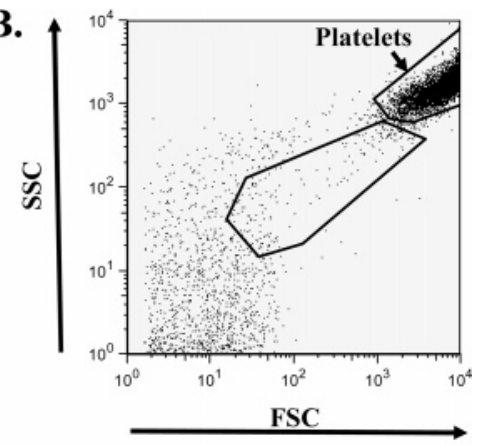

Figure 2. FACS analysis of (A) whole blood, (B) isolated platelets, and (C) microparticles generated from the platelets. Due to size differences between red blood cells and microparticles, the scale of the forward scatter (FSC) and side scatter (SSC) is altered between $A$ and $B-C$.

$0.1 \%$ acetic acid, Solvent $\mathrm{B}=70 \%$ acetonitrile in $0.1 \%$ acetic acid). The LTQ mass spectrometer was operated in the data dependent mode where an initial MS scan recorded the mass to charge $(\mathrm{m} / \mathrm{z})$ ratios of parent ions over the mass range 300$2000 \mathrm{Da}$. The 10 most abundant ions were then selected for subsequent collisionally activated dissociation (CAD) and an MS/MS spectrum recorded. All MS/MS data were searched against a human database downloaded from NCBI (www. ncbi.nlm.nih.gov) using the Sequest program. ${ }^{26}$ A static modification of $57 \mathrm{Da}$ for cysteine residues and a differential modification of $16 \mathrm{Da}$ for methionine residues were employed in the search parameters. Peptide identifications were made according to standard criteria previously described ${ }^{27}$ In short, all peptides must have a $\Delta \mathrm{Cn}$ of at least 0.1 and cross correlation values of at least $1.9(+1$ charge), $2.5(+2$ charge) and 3.5 ( +3 charge). Additionally, all peptides must be fully tryptic. Protein assignments were only made if the protein had five or greater MS/MS hits for at least two different peptides passing the above criteria. Last, manual validation of at least one MS/MS spectrum per protein was completed as a final confirmation of peptide and thus protein identification.

\section{Results and Discussion}

Preparation of Platelet-Derived Microparticles. Platelets can be activated by a number of agonists to generate microparticles. ${ }^{28}$ In this study, we used $10 \mu \mathrm{M}$ ADP as an agonist because; (1) it is physiologically relevant, (2) it avoids addition of exogenous protein based agonists which can complicate the proteomic analysis, and (3) it results in extensive platelet activation within $10 \mathrm{~min}$. To verify the generation of microparticles, platelets and platelet-derived microparticles were separated by centrifugation $(710 \times g$ for $15 \mathrm{~min})$ and analyzed by FACS. As shown in Figure 2, red blood cell contamination was nonproblematic in whole blood (Figure 2A), purified platelets contained less than $1 \%$ microparticles (Figure 2B), and purified microparticles contained less than $3 \%$ platelets (Figure 2C). To survey the platelet-derived microparticle proteome by mass spectrometry, microparticle proteins were separated by SDS-PAGE on a $4-20 \%$ gel (Figure 1), sliced into 26 bands of equal size and analyzed by LC-MS/MS. By using the above approach, we have identified 578 proteins from platelet-derived microparticles (See Supplemental Data Table 1). Previous work on the platelet proteome involved the analysis of individual spots from 2D gel electrophoresis and identified $123^{29}$ and $311^{30}$ proteins, respectively. A comparison of the number of proteins reported from the two earlier studies on the platelet proteome with those identified in the present work on platelet-derived microparticles is shown in Figure 3. Proteins common to two or more of the samples are shown in areas where the circles overlap. Note that of the 528 proteins reported here, approximately 380 have not been identified in previous work on the platelet proteome.

Platelet Proteins Detected in the Microparticle Preparation. Microparticles display membrane proteins that are specific to the parent cell. ${ }^{7-9}$ Indeed, a number of platelet membrane proteins were detected in the present study. These include surface receptors known to bind thrombospondin (von Willebrand factor) such as glycoproteins Ib, IIb, IIIa, IV, V, and IX. The glycoprotein IIb-IIIA complex is the major fibrinogen receptor on platelets and plays an important role in the release of microparticles. ${ }^{31}$ Also identified were a number of proteins involved in the coagulation process. These include fibrinogen, von Willebrand factor, coagulation factors V and XIII, thrombospondin, and protein $\mathrm{S}$. Integrins and other receptor proteins were also detected. Figure 4A shows an MS/MS spectrum of the precursor $[\mathrm{M}+2 \mathrm{H}]^{2+}$ ion at $744.35 \mathrm{~m} / \mathrm{z}$ derived from the peptide, AGDISCNADINPLK. This peptide is found in integrin$\alpha_{2}$ (CD49b), a member of the intregrin family of proteins that 


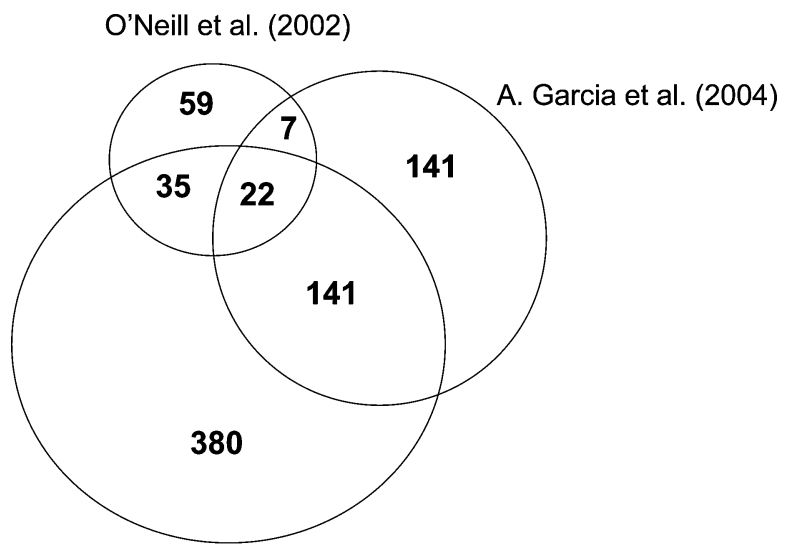

Platelet-derived microparticle sample

Figure 3. Comparison of the number of proteins identified in platelets from two earlier studies, ${ }^{29,30}$ and reported here from work on a platelet-derived microparticle preparation. Proteins common to two or more of the samples are shown in areas where the circles overlap.

\section{AGDISCNADINPLK}

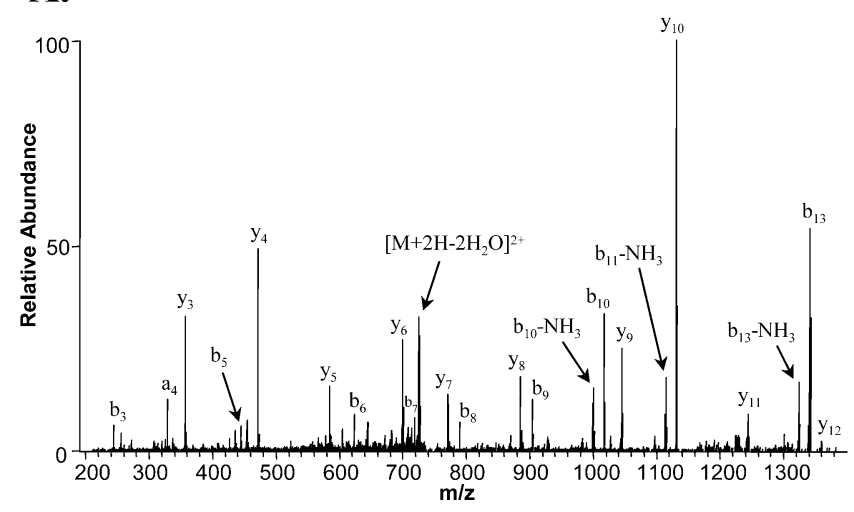

\section{B. CSNPAVVFVTR}

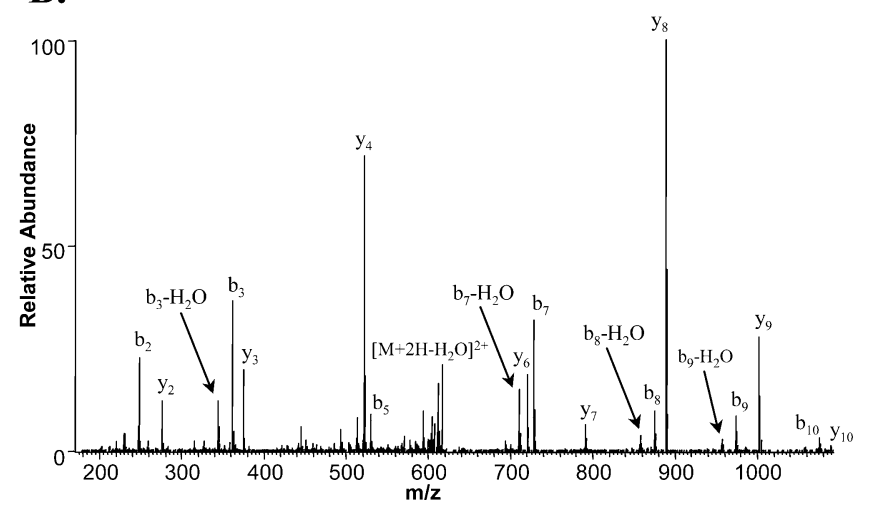

Figure 4. Protein identification from a sample preparation of platelet-derived microparticles. MS/MS spectra of recorded on $[\mathrm{M}+2 \mathrm{H}]^{2+}$ ions at: (A) $\mathrm{m} / \mathrm{z} 744.35$ corresponding to a peptide from integrin $\alpha_{2}$ (CD49b) and (B) $m / z 625.74$ corresponding to a peptide derived from RANTES (CCL5). Fragment ions of type $b$ and $y$ are labeled on the spectra.

function as receptors for extracellular matrix proteins such as laminin and collagen. Integrin- $\alpha_{2}$ participates in cell-surface mediated signaling and cell adhesion and is known to be expressed on both platelets and activated monocytes. ${ }^{32}$
Additional known platlet proteins identified on this plateletderived microparticle sample include the chemokines, platelet factor 4 (CXCL4), pro-platelet basic protein (CXCL7), and RANTES (CCL5). Platelet factor 4 is believed to have a role in inflammation and wound repair as it can promote coagulation by binding heparin-type molecules on the endothelial surface of blood vessels and thus inhibits local antithrombin activity. ${ }^{33}$ Pro-platelet basic protein is a growth factor and activator of neutrophils after proteolytic processing to form neutrophilactivating peptide-2. The third chemokine, RANTES, is a major chemoattractant for monocytes and activated lymphocytes that signals for the release of histamine from basophils and activates eosinophils. Prior to this investigation, only the mRNA transcript for RANTES had been detected in platelets using genomic techniques. ${ }^{34}$ Evidence that the RANTES protein is actually expressed in platelet derived microparticles is shown in Figure 4B. This MS/MS spectrum recorded on the $[\mathrm{M}+2 \mathrm{H}]^{2+}$ ion at $625.74 \mathrm{~m} / z$. corresponds to the RANTES peptide, CSNPAVVFVTR.

Proteins Not Previously Characterized in Platelets. Approximately 380 proteins were found in the platelet-derived microparticle sample that had not previously detected in platelets. One of these proteins, phosphomevalonate catalyzes the conversion of mevalonate-5-phosphate to mevalonate-5diphosphate in the cholesterol biosynthesis pathway. Although the phosphomevalonate kinase was previously thought to be localized to the peroxisomal region, recent work has detected the kinase in the cytosol of human fibroblasts, liver, and heart tissue. $^{35}$ Observation of the kinase in the platelet-derived microparticle sample is interesting as microparticles have been linked to cardiovascular diseases. ${ }^{28}$ Novel proteins predicted present on platelets from open reading frames of genomic sequences and identified here in platelet-derived microparticles include hypothetical gene products FLJ20245, PRO1855, KIAA0152, and KIAA0851. One additional predicted gene product KIAA0830, was previously found in platelets ${ }^{29}$ and was also observed in the present work on the platelet-derived microparticle sample. Also observed in this sample were a number of nuclear proteins. These are of interest since neither microparticles nor platelets contain a nucleus. Whether the observed nuclear proteins are functionally significant or just a consequence of platelet budding from the precursor megakaryocyte remains to be investigated.

Annotation of Proteins from Platelet-Derived Microparticles. Pie charts in Figure 5 show the 578 proteins identified on the platelet-derived microparticle sample distributed among the following categories: (A) cellular processes, (B) molecular function, and (C) sub-cellular localization. Within the first category (Figure 5A), the largest number of proteins is involved in signal transduction and cell communication (28\%). Smaller numbers of proteins are found in processes such as metabolism and energy pathways (22\%), protein metabolism (15\%), cellular organization and biogenesis (14\%), and transport (10\%). Similar results were obtained in earlier mass spectrometry studies on platelets. ${ }^{29,30}$

Molecular functions for the proteins identified on the platelet-derived microparticle sample are shown in Figure 5B. The largest number of proteins is found in the subsection entitled, enzymes (22\%). Smaller numbers of entries are identified in the subsections, others and unknown (21\%), cytoskeletal proteins (14\%), transport proteins (9\%), G-proteins (8\%), and kinases and phosphatases (7\%). Sub-cellular locations for proteins identified in the platelet-derived microparticle sample 

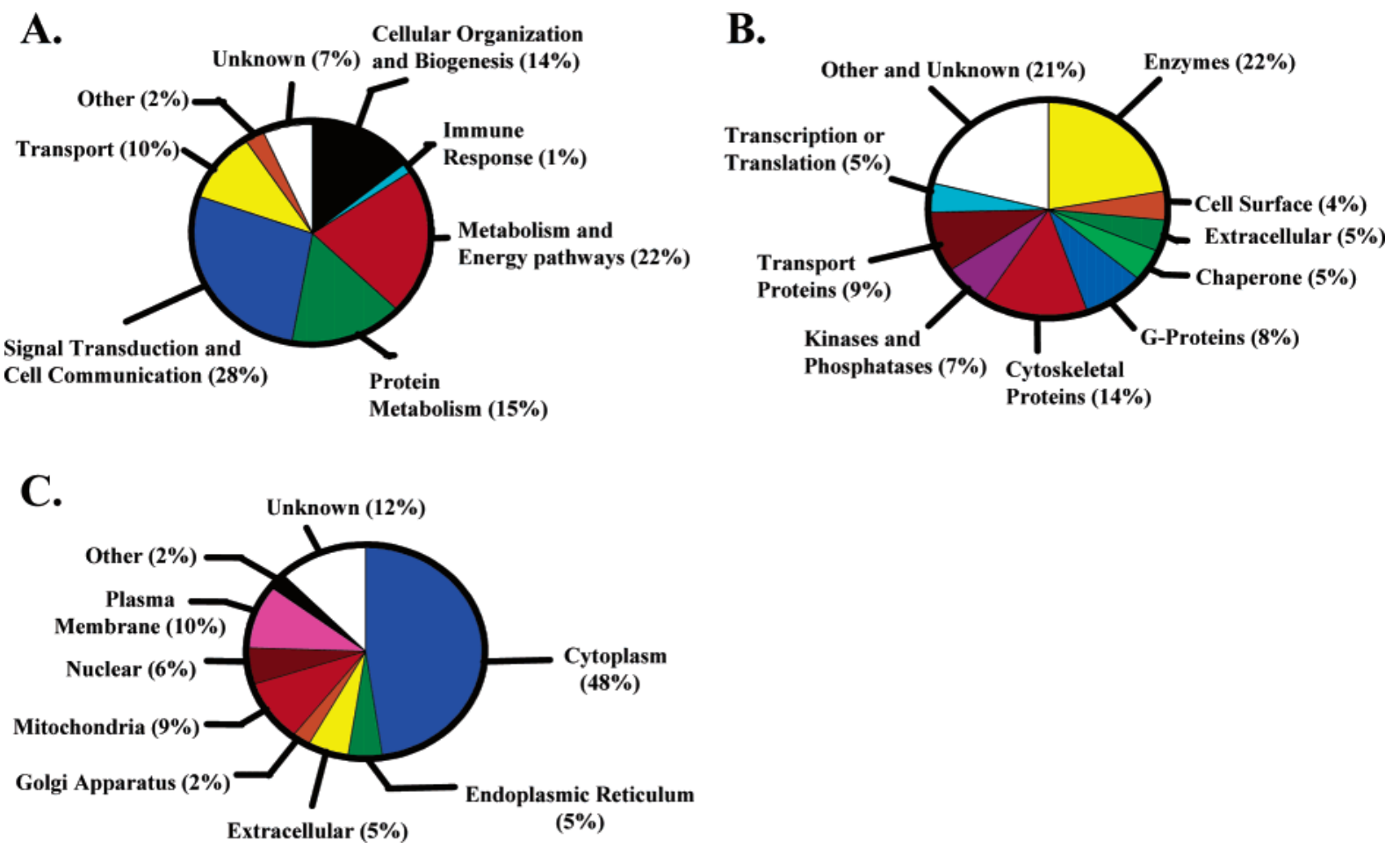

Figure 5. Pie charts showing the 578 proteins identified in this study distributed into the following categories: (A) cellular processes, (B) molecular function, and (C) sub-cellular localization.

are shown in Figure 5C. Nearly half of the observed proteins come from the cytoplasm (48\%). Smaller numbers of proteins are derived from unknown localizations (12\%), the plasma membrane $(10 \%)$, and mitochondria $(9 \%)$.

\section{Conclusions}

We have used 1D SDS-PAGE and LC-MS/MS methods to generate an extensive list of proteins observed in a plateletderived microparticle sample. This is the first MS based proteomics data set to be obtained from a platelet-derived microparticle sample preparation. Of the 578 proteins identified, 380 had not been detected previously in platelets..$^{29,30}$ Included in the data set are a number of transmembrane and cell surface proteins, proteins believed to be involved in microparticle formation and several signal transduction proteins. Very recently, a report has identified 83 different proteins in a plasma-derived microparticle sample using $2 \mathrm{D}$ gels and MALDI-MS. ${ }^{36}$ The majority of the proteins identified in that study were detected in our work as part of the platelet-derived microparticle proteome, consistent with a previous study that indicated that platelet-derived microparticles are the most abundant type of microparticle circulating in human blood. ${ }^{37}$ Future studies on proteins identified in the present work should define the roles that particular proteins play in both microparticle formation and possibly microparticle function in cardiovascular diseases.

Acknowledgment. Funding from the National Institute of Health to D.F.H. (GM37537) and K.L. (HL58108) and the Ford Foundation to B.A.G. are gratefully acknowledged.

Supporting Information Available: Table showing identified proteins, prev IDs, genes, GIs, Swiss-Pro nos., functions, and molc. classes. This material is available free of charge via the Internet at http://pubs.acs.org.

\section{References}

(1) Nieuwland, R.; Berckmans, R. J.; McGregor, S.; Boing, A. N.; Romijn, F. P.; Westendorp, R. G.; Hack, C. E.; Sturk, A. Blood 2000, 95, 930-935.

(2) Nomura, S.; Suzuki, M.; Katsura, K.; Xie, G. L.; Miyazaki, Y.; Miyake, T.; Kido, H.; Kagawa, H.; Fukuhara, S. Atherosclerosis 1995, 116, 235-240.

(3) Minagar, A.; Jy, W.; Jimenez, J. J.; Sheremata, W. A.; Mauro, L. M.; Mao, W. W.; Horstman, L. L.; Ahn, Y. S. Neurology 2001, 56, 1319-1324.

(4) Bernal-Mizrachi, L.; Jy, W.; Jimenez, J. J.; Pastor, J.; Mauro, L. M.; Horstman, L. L.; de Marchena, E.; Ahn, Y. S. Am. Heart J. 2003, 145, 962-970.

(5) Combes, V.; Simon, A. C.; Grau, G. E.; Arnoux, D.; Camoin, L.; Sabatier, F.; Mutin, M.; Sanmarco, M.; Sampol, J.; Dignat-George, F. J. Clin. Invest. 1999, 104, 93-102.

(6) Wolf, P. Br. J. Haematol. 1967, 13, 269-288.

(7) Fritzsching, B.; Schwer, B.; Kartenbeck, J.; Pedal, A.; Horejsi, V.; Ott, M. Immunol. 2002, 169, 5531-5537.

(8) Jimenez, J. J.; Jy, W.; Mauro, L. M.; Soderland, C.; Horstman, L. L.; Ahn, Y. S. Thromb Res. 2003, 109, 175-180.

(9) Nusbaum, P.; Laine, C.; Bouaouina, M.; Seveau, S.; Cramer, E. M.; Masse, J. M.; Lesavre, P., Halbwachs-Mecarelli, L. J. Biol. Chem. 2005, 280, 5843-5853.

(10) Falati, S.; Liu, Q, Gross, P.; Merrill-Skoloff, G.; Chou, J.; Vandendries, E.; Celi, A.; Croce, K.; Furie, B. C.; Furie, B. J. Exp. Med. 2003, 197, 1585-1598.

(11) Barry, O. P.; Pratico, D.; Savani, R. C.; FitzGerald, G. A. J. Clin. Invest. 1998, 102, 136-144.

(12) Distler, J. H.; Jungel, A.; Huber, L. C.; Seemayer, C. A.; Reich, C. F.; Gay, R. E., III; Michel, B. A.; Fontana, A.; Gay, S.; Pisetsky, D. S.; Distler, O. Proc. Natl. Acad. Sci. U.S.A. 2005, 102, 2892-2897.

(13) Mesri, M.; Altieri, D. C. J. Biol. Chem. 1999, 274, 23111-23118.

(14) Pfister, S. L. Hypertension 2004, 43, 428-433.

(15) Brill, A.; Dashevsky, O.; Rivo, J.; Gozal, Y.; Varon, D. Cardiovasc. Res. 2005, 67, 30-38.

(16) Janowska-Wieczorek, A.; Wysoczynski, M.; Kijowski, J.; MarquezCurtis, L.; Machalinski, B.; Ratajczak, J.; Ratajczak, M.Z. Int. J. Cancer 2005, 113, 752-760.

(17) Horstman, L. L.; Ahn, Y. S. Crit. Rev. Oncol. Hematol. 1999, 30 , $111-142$

(18) Gasser, O.; Hess, C.; Miot, S.; Deon, C.; Sanchez, J. C.; Schifferli, J. A. Exp. Cell. Res. 2003, 285, 243-257 
(19) Janowska-Wieczorek, A.; Majka, M.; Kijowski, J.; Baj-Krzyworzeka, M.; Reca, R.; Turner, A. R.; Ratajczak, J.; Emerson, S. G.; Kowalska, M. A.; Ratajczak, M. Z. Blood 2001, 98, 3143-3149.

(20) Diamant, M.; Tushuizen, M. E.; Sturk, A.; Nieuwland, R. Eur. J. Clin. Invest. 2004, 34, 392-401.

(21) Fox, J. E. J. Clin. Invest. 1985, 76, 1673-1683.

(22) Forlow, S. B.; McEver, R. P.; Nollert, M. U. Blood 2000, 95, $1317-$ 23.

(23) Laemmli, U. K. Nature 1970, 227, 680-685.

(24) Shevchenko, A.; Wilm, M.; Vorm, O.; Mann, M. Anal. Chem. 1996, $68,850-858$.

(25) Martin, S. E.; Shabanowitz, J.; Hunt, D. F.; Marto, J. A. Anal. Chem. 2000, 72, 4266-4274.

(26) Eng, J. K.; McCormack, A. L.; Yates, J. R., III J. Am. Soc. Mass Spectrom. 1994, 5, 976-989.

(27) Washburn, M. P.; Wolters, D.; Yates, J. R. III. Nat. Biotechnol. 2001, 19, $242-247$

(28) VanWijk, M. J.; VanBavel, E.; Sturk, A.; Nieuwland, R. Cardiovasc. Res. 2003, 59, 277-287.

(29) O’Neill, E. E.; Brock, C. J.; von Kriegsheim, A. F.; Pearce, A. C.; Dwek, R. A.; Watson S. P.; Hebestreit, H. F. Proteomics 2002, 2, 288-305.
(30) Garcia, A.; Prabhakar, S.; Brock, C. J.; Pearce, A. C.; Dwek, R. A.; Watson, S. P.; Hebestreit, H. F.; Zitzmann, N. Proteomics 2004, 4, 656-668.

(31) Gemmell, C. H.; Sefton, M. V.; Yeo, E. L. J. Biol. Chem. 1993, 268, 14586-14589.

(32) Gadgil, H. S.; Pabst, K. M.; Giorgianni, F.; Umstot, E. S.; Desiderio, D. M.; Beranova-Giorgianni, S.; Gerling, I. C.; Pabst, M. J. Proteomics 2003, 3, 1767-1780.

(33) Senior, R. M.; Griffin, G. L.; Huang, J. S.; Walz, D. A.; Deuel, T. F. J. Cell Biol. 1983, 96, 382-385.

(34) McRedmond, J. P.; Park, S. D.; Reilly, D. F.; Coppinger, J. A.; Maguire, P. B.; Shields, D. C.; Fitzgerald, D. J. Mol. Cell Proteomics. 2004, 3, 133-144.

(35) Hogenboom, S.; Tuyp, J. J.; Espeel, M.; Koster, J.; Wanders, R. J.; Waterham, H. R. J. Lipid Res. 2004, 45, 697-705.

(36) Jin, M.; Drwal, G.; Bourgeois, T.; Saltz, J.; Wu, H. M. Proteomics 2005, 5, 1940-1952.

(37) Berckmans, R. J.; Neiuwland, R.; Boing, A. N.; Romijn, F. P.; Hack, C. E.; Sturk, A. Thromb. Haemost. 2001, 85, 639-646.

PR0500760 